\title{
INFLUENCE OF LOW-PROTEIN LEVELS FORTIFIED WITH METHIONINE AND ENERGY ON PRODUCTIVE AND REPRODUCTIVE PERFORMANCE OF SILVER MONTAZAH LAYING HENS
}

\author{
A. A. Alderey \\ Animal Production Research Institute, Agricultural Research Center, Ministry of Agriculture, Dokki, \\ Cairo, Egypt.
}

(Received 13/1/2020, accepted 25/2/2020)

\section{SUMMARY}

$\mathrm{T}$ The objective of the present experiment to determine the extent to which the crude protein $(\mathrm{CP})$ content of laying hen diets can be reduced, based on fortified with methionine (Met.) to reach a level of sulfur amino acids equal with high-protein level and their effects on productive and reproductive performance of silver Montazah laying hens during 24-40 wks of age. One hundred and eighty hens 24-weeks old were housed in individually cages in factorial experimental design (2X3) involves 30 birds in each treatment. The experimental diets were formulated with two dietary metabolizable energy levels (low energy $=$ 2700 and high energy $=2850 \mathrm{kcal} \mathrm{ME} / \mathrm{kg}$ diet) and three dietary protein levels $14 \%$ low crude protein; $16 \%$ moderate crude protein and $18 \%$ high crude protein. The diets of 14 and $16 \% \mathrm{CP}$ were fortified with methionine to reach the same level of SAA $18 \% \mathrm{CP}$-diet. Feeds and water were offered ad libitum. Fertility and hatchability percentage were determined at 37, 38 and 39 wk of age. All hens from each treatment group were artificially inseminated twice a week with a fixed volume of diluted semen (1:1) from cockerels fed diet containing $16 \%$ $\mathrm{CP}$ and $2750 \mathrm{kcal} / \mathrm{kg}$ diet. Results are summarized as follows: Significant increases were observed in final body weight (FBW), body weight change (BWC), metabolizable energy efficiency ratio (EER) feed conversion ratio (FCR), Egg production parameters; egg number (EN), egg weight (EW), daily egg mass (EM), hen-day egg production rate\% (HDEP), cholesterol level in blood plasma and economic efficiency of feed parameters (EEF) due to feeding on high-energy diets, while birds fed on low-energy diets resulted in significantly $(\mathrm{P} \leq 0.01)$ increased in feed intake, daily protein intake, daily energy intake and daily methionine intake than that fed highenergy diet. The same manner was observed in respect of protein levels, where increasing protein content in the diet had a significant improvement $(\mathrm{P} \leq 0.01)$ in final body weight, change (BWC), daily protein intake, energy efficiency ratio, feed conversion ratio, egg number, egg weight, egg mass, hen day egg production rate, AST, and ALT in blood plasma. Interaction between energy and protein levels were significant effects on most studied traits, there were positive effects of different protein levels at high energy level on body weight, body weight change, energy efficiency ratio, feed conversion, egg number, daily egg mass, hen-day egg production rate $\%$, egg fertility $\%$, hatchability $\%$, chick weight, most blood traits and economic efficiency of feed. However, neither energy nor protein levels significantly affected on egg quality, egg fertility percentage and chick weight. Based on performance outcomes hens fed high-energy diet with $14 \%$ or $16 \%$ protein level fortified with DLmethionine succeed in recording egg number and hen-day egg production rate like those fed on $18 \%$ protein. It could be concluded that reducing protein level fortified with DL-methionine in Montazah laying hens diets had beneficial effects on some traits but not all traits. From economic analysis of this study it can be used diets containing $2850 \mathrm{kcalME} / \mathrm{kg}$ diet with $14 \%$ or $16 \% \mathrm{CP}$ fortified with methionine in feeding Silver Montazah laying hens during 24-40 weeks of age without negative effect on profitability.

Keywords: Dietary metabolizable energy and crude protein levels, methionine, Montazah laying hens productive and reproductive performance.

\section{INTRODUCTION}

Protein and amino acids are the most cost ingredient in the diet. The efficiency of dietary protein utilization depends on the amount, composition, and digestibility of the amino acids (AA) in the diet, hence determination of optimum level of amino acids in feed formulation is fundamental not only in economics of production also in addition to reduction of nitrogen loss in poultry faces which alleviate of environmental pollution. 
With acute increases in energy and protein cost, it is should good understand of how to maximize benefits of dietary feed rations at different protein, amino acids and energy levels to obtain optimize productive and reproductive performance. Increasing levels of protein (Nahashon et al., 2010, Keshavarz and Nakajima. 1995, Leeson, 1989), methionine (Keshavarz, 1995), and lysine (Zimmerman, 1997) improved production parameters especially egg weights. However, a reduction in the dietary concentration of CP may result in unbalanced amino acid concentrations and may also change the optimal requirements of the limiting amino acids (methionine, lysine) at lower dietary levels of $\mathrm{CP}$ in the same time excess of the requirements from amino acids may break down production through several interactions and may occur in $\mathrm{N}$ environmental pollution. Similarly, If dietary metabolizable energy needs to be reduced, then essential amino acids also should be reduced, but to a lesser extent. The prospect of lowering dietary protein has become actuality because of the availability of Lys, Met, Thr, and Trp in the market.

Many researchers have been published on Met and TSAA requirements and their effects on laying hen performance. However, there is a wide range in recommended requirement of Met. and TSAA for laying hens. Saki et al. (2012) who found that increasing Met. level from 0.24 to $0.34 \%$ with constant energy level $2830 \mathrm{kcal} / \mathrm{kg}$ resulted in significantly increased egg production, egg weight, egg mass, egg content, and feed intake and improved feed conversion ratio $(\mathrm{p} \leq 0.05)$. However, further Met. increases, from 0.34 to $0.49 \%$, no longer influenced these parameters. Ahmad et al. (1997) indicated that performance of laying hens had not affected as a result feeding on TSAA levels ranging from 580 to $660 \mathrm{mg} / \mathrm{h} / \mathrm{d}$. Meluzzi et al. (2001) fed laying hens on diets at different protein concentrations: 170 (control), 150 and $130 \mathrm{~g} / \mathrm{kg} \mathrm{CP}$ with adequate concentrations of lysine, sulfur amino acids, tryptophan and threonine and found that a low-CP diet supplemented with amino acids sustained performance during the initial $8 \mathrm{wk}$ of the experiment, after which $\mathrm{EP}$ and EM reduced compared with birds fed diets with the recommended CP level.

In general, nutrient specifications and amino acid specification should be adjusted to the economic conditions including sources income and return.

The present study was conducted to determine how much dietary crude protein could be reduced, by fortified with methionine to reach constant level of sulfur amino acid and reflected it on productive and reproductive performance of Montazah laying hens during production phase from 24 to 40 weeks of age.

\section{MATERIALS AND METHODS}

The experiment was carried out at Gimmizah Research Station, Animal Production Research Institute, Agricultural. Research. Center, Ministry of Agriculture. A total of 180 Silver Montazah laying hens 24weeks old used in this experiment. The experimental birds were reared in floor pens up to 27 weeks of age then they were transferred into individual battery cages and given one week to adapt in battery system. The birds were randomly allocated to six treatment group had nearly similar body weight in factorial experimental design (2X3). the experimental diets consists of two metabolizable energy (ME) levels, 2700 as low energy and 2850 as high energy $\mathrm{kcal} / \mathrm{kg}$, and three dietary protein levels which referred to $18 \%=$ high $\mathrm{CP}, 16 \%=$ medium $\mathrm{CP}$, or $14 \%=$ low CP. The levels of 14 and $16 \% \mathrm{CP}$ fortified with amino acid methionine to be equated with diet content $18 \%$ protein of SAA. The proposal of reducing protein diets fortified with amino acid methionine to equal the content of the high- protein diets from SAA and reflected on productive and reproductive performance as well as reducing the cost of the diet. The composition of the experimental diets is presented in Table (1). The experiment period was lasted to 40-wks age. Feed and water were provided ad-libitum throughout the experiment. Hens were maintained on a 16L: 8D during the experimental period.

\section{Measurements:}

Live body weight of each hen was recorded in the beginning and the end of experimental period. Feed intake, egg number $(\mathrm{EN})$ and egg weights $(\mathrm{EW})$ were recorded while, daily protein intake, daily energy intake, feed conversion ratio (FCR), egg mass (EM), protein efficiency ratio (PER) and energy efficiency ratio were calculated.

At 34, 35 and 36 wk of age, 30 eggs per treatment group were collected at random to determine the egg quality measurements. Shape index was calculated by divided widths into lengths multiple in 100 . The weights of yolk, albumen, and shell plus membranes were estimated. While, albumen height, yolk height and 
Table (1): The composition and calculated analysis of the experimental diets fed to Silver Montazah laying hens.

\begin{tabular}{|c|c|c|c|c|c|c|}
\hline Ingredient & 1 & 2 & 3 & 4 & 5 & 6 \\
\hline Yellow corn & 65.50 & 62.50 & 57.40 & 67.35 & 62.70 & 59.30 \\
\hline Soybean meal 44\% CP & 13.0 & 20.50 & 25.40 & 14.81 & 20.50 & 25.32 \\
\hline Corn gluten meal $62 \% \mathrm{CP}$ & 2.90 & 2.50 & 3.00 & 2.50 & 3.00 & 3.70 \\
\hline Wheat bran & 8.23 & 4.52 & 3.60 & 4.00 & 2.237 & 0.00 \\
\hline Limestone & 7.90 & 7.72 & 7.70 & 7.50 & 7.50 & 7.60 \\
\hline Di-calcium phosphate & 1.60 & 1.60 & 1.60 & 1.60 & 1.60 & 1.60 \\
\hline Soya oil & 0.00 & 0.00 & 0.70 & 1.35 & 1.8 & 1.88 \\
\hline Sodium chloride & 0.30 & 0.30 & 0.30 & 0.30 & 0.30 & 0.30 \\
\hline *Vit. \& Min. Premix & 0.30 & 0.30 & 0.30 & 0.30 & 0.30 & 0.30 \\
\hline Lysine (Lysine $\mathrm{HCl}$ ) & 0.15 & 0.00 & 0.00 & 0.11 & 0.00 & 0.00 \\
\hline Methionine & 0.12 & 0.06 & 0.00 & 0.13 & 0.063 & 0.00 \\
\hline Total & 100 & 100 & 100 & 100 & 100 & 100 \\
\hline \multicolumn{7}{|l|}{ **Calculated analysis } \\
\hline Crude Protein \% & 13.84 & 16.04 & 17.9 & 13.98 & 16.00 & 17.92 \\
\hline $\mathrm{ME}(\mathrm{kcal} / \mathrm{kg})$ & 2703 & 2701 & 2703 & 2850 & 2849 & 2845 \\
\hline Crude fiber $\%$ & 3.45 & 3.52 & 3.62 & 3.16 & 3.26 & 3.28 \\
\hline Ether Extract\% & 3.18 & 2.918 & 3.42 & 4.35 & 4.59 & 4.47 \\
\hline Calcium \% & 3.449 & 3.40 & 3.40 & 3.31 & 3.31 & 3.25 \\
\hline Non-phytate P.\% & 0.422 & 0.426 & 0.432 & 0.423 & 0.419 & 0.423 \\
\hline Lysine, $\%$ & 0.735 & 0.806 & 0.938 & 0.733 & 0.798 & 0.926 \\
\hline Methionine, $\%$ & 0.398 & 0.368 & 0.338 & 0.408 & 0.376 & 0.346 \\
\hline Meth. \& Cyst. & 0.644 & 0.645 & 0.644 & 0.652 & 0.651 & 0.650 \\
\hline Feed cost L.E/kg & 4.616 & 4.747 & 4.974 & 4.804 & 5.004 & 5.212 \\
\hline \multicolumn{7}{|c|}{ 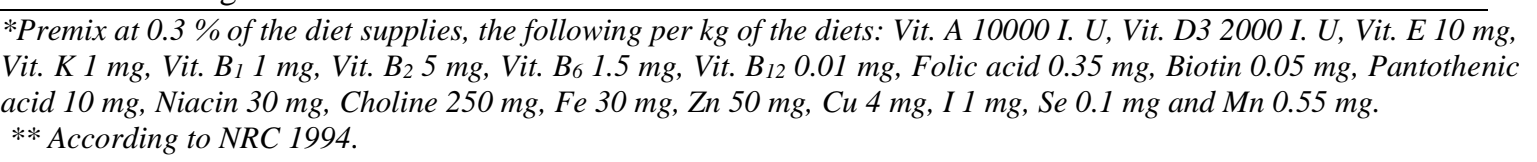 } \\
\hline \multicolumn{7}{|c|}{$\begin{array}{l}\text { yolk diameter were measured by using a steel vernier caliper. But shell thickness was measured using a } \\
\text { micrometer screw gauge. Thereafter albumen weight was calculated by difference between total egg weight } \\
\text { and the weight of shell plus yolk. Yolk index was calculated as yolk height } \times 100 \text { divided by yolk diameter. } \\
\text { Haugh units score was calculated according to Larbier and Leclercq }(1994) \text {, as follows: Haugh units }=100 \\
\log \left(\mathrm{H}+7.57-1.7 \mathrm{w}^{0.37}\right) \text {. Egg specific gravity was calculated according to Harms et al. }(1990) \text { while Egg } \\
\left.\text { surface area }(\mathrm{ESA})=3.9782 \mathrm{EW}^{0.7056} \text { (Carter, } 1974,1975\right) \text {. }\end{array}$} \\
\hline \multicolumn{7}{|c|}{$\begin{array}{l}\text { Fertility and hatchability percentage were determined at } 37,38 \text { and } 39 \text { wk of age. All hens from each } \\
\text { treatment group were artificially inseminated twice a week with a fixed volume of diluted semen (1:1) from } \\
\text { twenty cockerels fed diet containing } 16 \% \mathrm{CP} \text { and } 2750 \mathrm{kcal} / \mathrm{kg} \text { diet (same strain and age). Three hatches } \\
\text { were taken, each of hatch a total of } 300 \text { eggs were collected during seven consecutive days and stored at } 17 \mathrm{o} \\
\mathrm{C} \text { and } 70 \% \text { relative humidity prepare to set for incubator. At a day } 18 \text { of incubation, eggs were candled to } \\
\text { calculate fertility. At the end of incubation hatched chicks were collected and weighed. Blood samples were } \\
\text { taken from brachial vein in heparin-tube. After that the samples was centrifuged at } 4000 \mathrm{rpm} \text { for } 10 \text { min. to } \\
\text { determine plasma concentrations of total protein, albumin, glucose, activity transaminases (AST and ALT) } \\
\text { and cholesterol by using commercial kits while, plasma globulin level was determined as plasma total } \\
\text { protein minus that of albumin ignoring content of blood plasma from fibrinogen. }\end{array}$} \\
\hline
\end{tabular}

Economic efficiency of feed (EEF) was calculated according to:

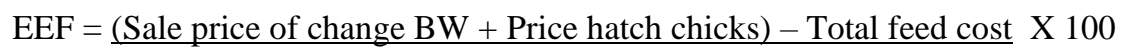




\section{Statistical Analyses:}

A factorial arrangement $(2 \times 3)$ in a completely randomized design was performed; two dietary ME levels (2700 and $2850 \mathrm{kcal} / \mathrm{kg}$ ) and three protein levels (14, 16 and 18\%). The data were analyzed according to General Liner Model (GLM) procedure by means of two- way analysis of variance using SPSS computer program (SPSS, 2011). The following mathematical model was used:

$Y i j k=\mu+M E i+P j+(M E P) i j+e i j k$.

Where Yijk $=$ An observation. $\mu=$ Overall mean. MEi $=$ The metabolizable energy effect $(i=1,2), P j=$ The protein level effect $(\mathrm{j}=1,2$ and 3$),(\mathrm{ME} \times \mathrm{P}) \mathrm{ij}=$ The interaction effect between energy and protein levels and eijk $=$ The random residual error.

Duncan's multiple range test was used to determine the significant differences among means of different variables (Duncan, 1955).

\section{RESULTS AND DISCUSION}

\section{Productive performance:}

\section{Body weight and feed intake:}

Increasing energy level from 2700 to $2850 \mathrm{kcal} / \mathrm{kg}$ diet resulted in significant improvement $(\mathrm{P} \leq 0.01)$ in FBW and BWC. On the other side, daily feed intake, daily protein intake (DFI) and daily energy intake exhibited significantly increased in response to feeding on low-energy diets as shown in Table (2). These results are agreement with findings by Nofal et al. (2018), who found that hens fed on the diet containing of $2800 \mathrm{kcal}$ ME $/ \mathrm{kg}$ displayed significantly $(\mathrm{P} \leq 0.01)$ increased in FBW and body weight gain than those fed on the diet $2600 \mathrm{kcal} \mathrm{ME} / \mathrm{kg}$. In addition, hens fed the low-energy diet consumed more feed than those fed on the high-energy diet. In the same trend, Omara et al. (2009) indicated that body weight gain for hens, were significantly increased because of feeding on the energy-sufficient diets, then that of hens fed on lower energy-diets. This may be attributed to the fact decreasing available energy for fat deposition with lowering dietary ME levels resulting in reducing body weight gain.

Although there were no significant differences in FBW of hens fed 16\% CP-diets than hens fed on 14 or 18\%-CP diets however, heavier body weight and BWC were recorded by hens fed $18 \%$ CP-diet than those fed on $14 \%$ CP-diets. Daily protein intake was significantly $(\mathrm{P} \leq 0.01)$ increased of hens fed $18 \%$-CP than those fed 14 or $16 \%$ CP-diet. Hens fed on 14 or $16 \%$ CP-diets fortified with methionine consumed more feed and daily energy intake was increased compared with those fed $18 \% \mathrm{CP}$-diet. Our results of the present study are agree with the findings of Yakout (2010) who found that reduction of dietary protein to $13 \%$ with supplementation of Met, Lys, Trp and Thr resulted in a significant decrease in BW and protein intake Compared with other levels $(15,15.5,17.51 \% \mathrm{CP})$. Also, Kumari et al. (2016) found that body weight was increased with increasing protein levels in the hen'diet. Van Emous et al. (2015) Latshaw and Zhao (2011), Gheisar et al. (2011), Keshavarz and Jackson (1992) and Wu et al. (2007) indicated that birds fed low-CP diet had a higher feed intake vs. high-CP diet which might be due to an amino acid appetite. Conversely Tenesa et al. (2016) who found there no significant differences in live body weigh when hens fed low crude protein diets $(17$ and $16.5 \% \mathrm{CP})$ supplemented with methionine, lysine and threonine than those fed on 17.5\% CP. Hassan et al. (2000) and Yakout (2000), showed that laying hens fed different CP levels revealed insignificant differences in body weight.

Hens fed diet containing $18 \% \mathrm{CP}$ and $2850 \mathrm{kcal} / \mathrm{kg}$ diet achieved highest FBW and BWC and lowest DFI compared with other treatment groups. In contrast hens received diet containing $14 \% \mathrm{CP}$ and $2700 \mathrm{kcal} / \mathrm{kg}$ diet recorded the lowest FBW, BWC than other treatment groups. It will be noticed that FBW of hens fed diets 14 or $16 \%$ CP fortified with methionine were similar in FBW to those fed $18 \% \mathrm{CP}$ at the high-energy level but hens fed on diet 14\% CP and low-energy level resulted in lighter FBW compared with other treatment groups. This enhanced if dietary metabolizable energy needs to be increased, then essential amino acids also should be increased. Where efficiency of utilization of amino acid in laying hens is affected by factors such as dietary energy concentration, amino acid balance in the diet, age of the birds, rate of lay and the proportions of the egg components. 
Table (2): Effect of dietary energy and protein levels fortified with methionine and their interactions on live body weight, daily feed intake, daily protein intake and daily energy intake of Silver Montazah laying hens.

\begin{tabular}{|c|c|c|c|c|c|c|}
\hline Treatment & $\begin{array}{l}\text { Initial } \\
\text { BW (g) }\end{array}$ & $\begin{array}{l}\text { Final BW } \\
\qquad(\mathrm{g})\end{array}$ & $\begin{array}{c}\text { Chang in } \\
\text { BW }(g)\end{array}$ & $\begin{array}{l}\text { Daily feed } \\
\text { intake }(\mathrm{g}) / \mathrm{h}\end{array}$ & $\begin{array}{l}\text { Daily protein } \\
\text { intake }(\mathrm{g}) / \mathrm{h}\end{array}$ & $\begin{array}{c}\text { Daily energy } \\
\text { intake } \\
(\mathrm{kcal}) / \mathrm{h}\end{array}$ \\
\hline \multicolumn{7}{|l|}{ Energy levels (E) } \\
\hline E $12700 \mathrm{kcal} / \mathrm{kg}$ & $\begin{array}{c}1452.20 \\
\pm 5.37\end{array}$ & $\begin{array}{l}1555.13 \\
\pm 5.82^{\mathrm{b}}\end{array}$ & $\begin{array}{l}102.93 \\
\pm 3.44^{\mathrm{b}}\end{array}$ & $\begin{array}{l}108.69 \\
\pm 0.54^{\mathrm{a}}\end{array}$ & $\begin{array}{c}17.44 \\
\pm 0.22^{\mathrm{a}}\end{array}$ & $\begin{array}{l}293.75 \\
\pm 1.47^{\mathrm{a}}\end{array}$ \\
\hline E $22850 \mathrm{kcal} / \mathrm{kg}$ & $\begin{array}{c}1454.49 \\
\pm 6.10\end{array}$ & $\begin{array}{l}1588.20 \\
\pm 5.94^{\mathrm{a}}\end{array}$ & $\begin{array}{l}135.71 \\
\pm 2.87^{\mathrm{a}}\end{array}$ & $\begin{array}{l}101.29 \\
\pm 0.47^{\mathrm{b}}\end{array}$ & $\begin{array}{c}16.22 \\
\pm 0.22^{\mathrm{b}}\end{array}$ & $\begin{array}{l}288.98 \\
\pm 1.35^{\mathrm{b}}\end{array}$ \\
\hline \multicolumn{7}{|l|}{$\begin{array}{l}\text { Significance level } \\
\text { Protein levels (P) }\end{array}$} \\
\hline P $1 \quad 14 \%$ & $\begin{array}{c}1454.43 \\
\pm 5.80\end{array}$ & $\begin{array}{c}1557.63 \\
\pm 6.92^{\mathrm{b}}\end{array}$ & $\begin{array}{l}103.20 \\
\pm 5.20^{\mathrm{b}}\end{array}$ & $\begin{array}{l}106.87 \\
\pm 0.79^{\mathrm{a}}\end{array}$ & $\begin{array}{l}15.02 \\
\pm 0.12^{\mathrm{c}}\end{array}$ & $\begin{array}{l}296.57 \\
\pm 1.44^{\mathrm{a}}\end{array}$ \\
\hline P $2 \quad 16 \%$ & $\begin{array}{c}1451.60 \\
\pm 6.29\end{array}$ & $\begin{array}{l}1574.10 \\
\pm 6.85^{\mathrm{ab}}\end{array}$ & $\begin{array}{l}122.50 \\
\pm 4.19^{\mathrm{a}}\end{array}$ & $\begin{array}{l}105.97 \\
\pm 1.01^{\mathrm{a}}\end{array}$ & $\begin{array}{l}17.04 \\
\pm 0.17^{\mathrm{b}}\end{array}$ & $\begin{array}{l}294.16 \\
\pm 1.56^{\mathrm{a}}\end{array}$ \\
\hline P $3 \quad 18 \%$ & $\begin{array}{c}1451.00 \\
\pm 8.76\end{array}$ & $\begin{array}{c}1583.27 \\
\pm 8.89^{\mathrm{a}}\end{array}$ & $\begin{array}{l}132.27 \\
\pm 6.19^{\mathrm{a}}\end{array}$ & $\begin{array}{l}102.13 \\
\pm 0.71^{\mathrm{b}}\end{array}$ & $\begin{array}{c}18.43 \\
\pm 0.13^{\mathrm{a}}\end{array}$ & $\begin{array}{l}283.37 \\
\pm 1.32^{\mathrm{b}}\end{array}$ \\
\hline $\begin{array}{l}\text { Significance level } \\
\text { Interactions }\end{array}$ & NS & $*$ & $* *$ & $* *$ & $* *$ & $* *$ \\
\hline E1 X P1 & $\begin{array}{c}1455.40 \\
\pm 7.62\end{array}$ & $\begin{array}{c}1534.87 \\
\pm 7.30^{c}\end{array}$ & $\begin{array}{r}79.47 \\
\pm 4.65^{\mathrm{e}}\end{array}$ & $\begin{array}{l}110.13 \\
\pm 0.52^{\mathrm{a}}\end{array}$ & $\begin{array}{c}15.51 \\
\pm 0.07^{\mathrm{d}}\end{array}$ & $\begin{array}{l}297.36 \\
\pm 1.39^{\mathrm{a}}\end{array}$ \\
\hline E1 X P2 & $\begin{array}{c}1449.00 \\
\pm 7.44\end{array}$ & $\begin{array}{l}1560.07 \\
\pm 7.31^{\mathrm{bc}}\end{array}$ & $\begin{array}{l}111.07 \\
\pm 2.06^{\mathrm{d}}\end{array}$ & $\begin{array}{l}111.00 \\
\pm 0.53^{\mathrm{a}}\end{array}$ & $\begin{array}{l}17.88 \\
\pm 0.08^{\mathrm{b}}\end{array}$ & $\begin{array}{l}300.26 \\
\pm 1.42^{\mathrm{a}}\end{array}$ \\
\hline E1 X P3 & $\begin{array}{l}1452.20 \\
\pm 12.52\end{array}$ & $\begin{array}{l}1570.47 \\
\pm 12.83^{\mathrm{ab}}\end{array}$ & $\begin{array}{l}118.27 \\
\pm 5.00^{\text {cd }}\end{array}$ & $\begin{array}{l}104.93 \\
\pm 0.83^{\mathrm{b}}\end{array}$ & $\begin{array}{l}18.93 \\
\pm 0.15^{\mathrm{a}}\end{array}$ & $\begin{array}{l}283.63 \\
\pm 2.25^{\mathrm{b}}\end{array}$ \\
\hline E2 X P1 & $\begin{array}{c}1453.47 \\
\pm 9.01\end{array}$ & $\begin{array}{l}1580.40 \\
\pm 8.44^{\mathrm{ab}}\end{array}$ & $\begin{array}{l}126.93 \\
\pm 4.15^{\mathrm{bc}}\end{array}$ & $\begin{array}{l}103.60 \\
\pm 0.90^{\mathrm{b}}\end{array}$ & $\begin{array}{c}14.52 \\
\pm 0.13^{\mathrm{e}}\end{array}$ & $\begin{array}{l}295.78 \\
\pm 2.57^{\mathrm{a}}\end{array}$ \\
\hline E2XP2 & $\begin{array}{l}1454.20 \\
\pm 10.37\end{array}$ & $\begin{array}{l}1588.13 \\
\pm 10.63^{\mathrm{ab}}\end{array}$ & $\begin{array}{l}133.93 \\
\pm 5.48^{\mathrm{b}}\end{array}$ & $\begin{array}{l}100.93 \\
\pm 0.58^{c}\end{array}$ & $\begin{array}{l}16.20 \\
\pm 0.10^{\mathrm{c}}\end{array}$ & $\begin{array}{l}288.06 \\
\pm 1.66^{\mathrm{b}}\end{array}$ \\
\hline E2 X P3 & $\begin{array}{l}1449.80 \\
\pm 12.68\end{array}$ & $\begin{array}{l}1596.07 \\
\pm 11.80^{\mathrm{a}}\end{array}$ & $\begin{array}{l}146.27 \\
\pm 4.09^{\mathrm{a}}\end{array}$ & $\begin{array}{l}99.33 \\
\pm 0.51^{\mathrm{c}}\end{array}$ & $\begin{array}{c}17.93 \\
\pm 0.10^{\mathrm{b}}\end{array}$ & $\begin{array}{l}283.10 \\
\pm 1.46^{\mathrm{d}}\end{array}$ \\
\hline Significance level & NS & $* *$ & $* *$ & $* *$ & $* *$ & $* *$ \\
\hline
\end{tabular}

$a, b . .$. For each of the main effects, means in the same column bearing different superscripts differ significantly

$N S=$ not significant $* P \leq 0.05, * *: P<0.01)$.

\section{Feed conversion (FCR):}

Data presented in Table (3) showed that there were significant differences in daily methionine intake, feed conversion ratio (FCR), protein conversion ratio (PER) and energy conversion ratio (EER) as affected by dietary ME and protein levels and their interaction. Increasing energy or protein levels in the diet resulted in decreasing in daily methionine intake and significant improvement in EER and FCR than other low levels of energy and protein. On the other side increasing in daily methionine intake of hens fed $16 \%$ or $14 \%$ CPdiet which consumed more feed than that fed high CP-diet. Furthermore, in addition EER and FCR were significant $(\mathrm{P} \leq 0.01)$ improved by increasing energy or protein levels resulted in gradually improvements in EER and FCR but PER was declined by increasing protein level in the diet. Results of interaction between studied factors revealed significant differences $(\mathrm{P} \leq 0.01)$ whereas EER and FCR were improved with high energy level and any protein levels. On the other hand FCR of hens fed 14\% CP and high energy diet were equivalent to those fed 18\% CP and low energy diet while the better FCR was obtained by hens fed highenergy and high-protein diets compared with other treatments. Our results herein agree with those results reported by Nofal et al. (2018) showed that feed conversion of laying hens was significantly $(\mathrm{P} \leq 0.01)$ improved with increasing energy level in the diets. In addition, some of researchers Mariey et al. (2009) noticed that increasing the nutrient density of diets resulted in significantly $(\mathrm{P} \leq 0.05)$ improvement in feed conversion. (Grobas et al., 1999, Harms et al., 2000, Bryant et al., 2005, and Wu et al., 2005) found 
Table (3): Effect of dietary energy and protein levels fortified with methionine and their interactions on daily methionine intake, protein efficiency ratio (PER), energy efficiency ratio (EER) and feed conversion (FCR) of Silver Montazah laying hens.

\begin{tabular}{lcccc}
\hline Treatment & $\begin{array}{c}\text { Daily Meth. } \\
\text { intake g/h }\end{array}$ & PER & EER & FCR \\
\hline Energy levels (E) & & & & \\
E 1 2700 kcal/kg & $0.400 \pm 0.01^{\mathrm{a}}$ & $0.559 \pm 0.01^{\mathrm{a}}$ & $9.45 \pm 0.09^{\mathrm{a}}$ & $3.50 \pm 0.03^{\mathrm{a}}$ \\
E 2 2850 kcal/kg & $0.381 \pm 0.01^{\mathrm{b}}$ & $0.499 \pm 0.01^{\mathrm{b}}$ & $8.91 \pm 0.08^{\mathrm{b}}$ & $3.12 \pm 0.03^{\mathrm{b}}$ \\
Significance level & $*$ & $* *$ & $* *$ & $* *$ \\
Protein levels (P) & & & & \\
P 1 14\% & $0.431 \pm 0.00^{\mathrm{a}}$ & $0.488 \pm 0.01^{\mathrm{c}}$ & $9.64 \pm 0.10^{\mathrm{a}}$ & $3.48 \pm 0.05^{\mathrm{a}}$ \\
P 2 16\% & $0.394 \pm 0.00^{\mathrm{b}}$ & $0.531 \pm 0.01^{\mathrm{b}}$ & $9.16 \pm 0.10^{\mathrm{b}}$ & $3.30 \pm 0.05^{\mathrm{b}}$ \\
P 3 18\% & $0.349 \pm 0.00^{\mathrm{c}}$ & $0.568 \pm 0.01^{\mathrm{a}}$ & $8.73 \pm 0.07^{\mathrm{c}}$ & $3.15 \pm 0.03^{\mathrm{c}}$ \\
Significance level & $*$ & $* *$ & $* *$ & $* *$ \\
Interactions & & & & \\
E1 X P1 & $0.438 \pm 0.00^{\mathrm{a}}$ & $0.517 \pm 0.01^{\mathrm{c}}$ & $9.91 \pm 0.12^{\mathrm{a}}$ & $3.67 \pm 0.05^{\mathrm{a}}$ \\
E1 X P2 & $0.408 \pm 0.00^{\mathrm{c}}$ & $0.570 \pm 0.01^{\mathrm{a}}$ & $9.57 \pm 0.11^{\mathrm{b}}$ & $3.54 \pm 0.05^{\mathrm{b}}$ \\
E1 X P3 & $0.355 \pm 0.00^{\mathrm{c}}$ & $0.591 \pm 0.01^{\mathrm{a}}$ & $8.86 \pm 0.09^{\mathrm{c}}$ & $3.28 \pm 0.03^{\mathrm{c}}$ \\
E2 X P1 & $0.423 \pm 0.00^{\mathrm{d}}$ & $0.460 \pm 0.01^{\mathrm{e}}$ & $9.36 \pm 0.12^{\mathrm{b}}$ & $3.28 \pm 0.04^{\mathrm{c}}$ \\
E2 X P2 & $0.380 \pm 0.00^{\mathrm{b}}$ & $0.492 \pm 0.004^{\mathrm{d}}$ & $8.75 \pm 0.08^{\mathrm{c}}$ & $3.07 \pm 0.03^{\mathrm{d}}$ \\
E2 X P3 & $0.344 \pm 0.00^{\mathrm{e}}$ & $0.545 \pm 0.01^{\mathrm{b}}$ & $8.60 \pm 0.10^{\mathrm{c}}$ & $3.03 \pm 0.03^{\mathrm{d}}$ \\
Significance level & $* *$ & $* *$ & $* *$ & $* *$ \\
\hline a,b $\ldots$. For each of the main effects, means in the same column bearing different superscripts differ significantly $* *: P<$ \\
0.01).
\end{tabular}

decreasing in FI and improving in FCR of laying hens by increasing dietary energy or fat in the diets. Hassan et al., (2000) and Yakout et al. (2004), who concluded that increasing protein level of layer diet, resulted in improving in FCR. Also, Salah Uddin et al. (1992) reported that feed conversion efficiency of layer hens increased in response to increasing dietary $\mathrm{CP}$ and ME levels. The same trend was observed by some of researchers who found that increasing dietary energy or fat decreased FI and improved FCR of laying hens (Grobas et al., 1999, Harms et al., 2000, Bryant et al., 2005, and Wu et al., 2005). Chaiyapoom and Tweesak (2005) found that protein conversion ratio was significantly improved with decreasing the protein consumption in laying hen $(\mathrm{P} \leq 0.01)$. Zeweil et al. (2011) reported that apparent $\mathrm{CP}$ digestibility was increased by decreasing protein and increasing methionine levels in laying hen diets significantly.

The impair in PER, EER and FCR when hens fed low energy diet may be attributed to increasing methionine level $(0.398$ and $0.368 \%)$ to keep constant level of SAA which is reflected increasing feed intake, increasing methionine intake. Saki et al. (2012) who found that increasing Methionine level from 0.24 to $0.34 \%$ with constant energy level $2830 \mathrm{kcal} / \mathrm{kg}$ resulted in significantly increased egg production, egg weight, egg mass, egg content, and feed intake and decreased feed conversion ratio $(\mathrm{p}<0.05)$. However, further Met increases, from 0.34 to $0.49 \%$, no longer influenced these parameters.

\section{Laying performance:}

Data listed in Table (4) showed that there significant effects $(\mathrm{P} \leq 0.01)$ in egg production traits as affected by dietary energy and protein levels fortified with methionine and their interactions whereas EN, EW, EM and HDEP significantly $(\mathrm{P} \leq 0.01)$ improved by inclusion high energy or increasing protein level in the diet, however birds fed a diet 16\% CP fortified with methionine were similar in EN, EW, EM and HDEP to those fed diet containing $18 \% \mathrm{CP}$ but hens fed $14 \% \mathrm{CP}$ fortified with methionine failed to achieve good performance in EP traits compared with other two levels of protein .

There is positive correlation between energy levels and protein levels on all EP parameters. Although hens fed diet containing $2700 \mathrm{kcal} / \mathrm{kg}$ diet and $14 \% \mathrm{CP}$ fortified with methionine recorded lowest value of EN, EW, EM and HDEP compared with other treatment groups however, at high energy level hens fed 14 and $16 \% \mathrm{CP}$ fortified with methionine were similar in EN and HDEP than those fed on 18\% CP. These results are in harmony with findings by Silva viana (2017) who indicated that reduction on dietary CP decreased egg weight and egg mass and impaired layer productivity, hens fed diets with $170 \mathrm{~g} \mathrm{CP} / \mathrm{kg}$ showed 
Table (4): Effect of dietary energy and protein levels fortified with methionine and their interactions on egg number egg weight (g), daily egg mass (g) and hen-day egg production rate \% of Montazah laying hens.

\begin{tabular}{|c|c|c|c|c|}
\hline Treatment & $\begin{array}{c}\text { Egg } \\
\text { number }\end{array}$ & $\begin{array}{l}\text { Egg weight } \\
(\mathrm{g})\end{array}$ & $\begin{array}{l}\text { Daily egg mass } \\
(\mathrm{g})\end{array}$ & $\begin{array}{c}\text { hen-day egg } \\
\text { production rate } \%\end{array}$ \\
\hline \multicolumn{5}{|c|}{ Energy levels (E) } \\
\hline E $12700 \mathrm{kcal} / \mathrm{kg}$ & $65.33 \pm 0.39^{b}$ & $50.10 \pm 0.19^{b}$ & $31.17 \pm 0.21^{b}$ & $62.22 \pm 0.38^{b}$ \\
\hline E $22850 \mathrm{kcal} / \mathrm{kg}$ & $66.56 \pm 0.28^{a}$ & $51.26 \pm 0.16^{\mathrm{a}}$ & $32.49 \pm 0.16^{\mathrm{a}}$ & $63.39 \pm 0.26^{\mathrm{a}}$ \\
\hline Significance level & $*$ & $* *$ & $*$ & ** \\
\hline \multicolumn{5}{|c|}{ Protein levels $(\mathrm{P})$} \\
\hline P $1 \quad 14 \%$ & $64.77 \pm 0.50^{\mathrm{b}}$ & $50.00 \pm 0.24^{\mathrm{b}}$ & $30.84 \pm 0.27^{\mathrm{b}}$ & $61.68 \pm 0.48^{\mathrm{b}}$ \\
\hline P $2 \quad 16 \%$ & $66.43 \pm 0.39^{a}$ & $50.86 \pm 0.19^{a}$ & $32.18 \pm 0.23^{\mathrm{a}}$ & $63.27 \pm 0.38^{a}$ \\
\hline P $3 \quad 18 \%$ & $66.63 \pm 0.30^{\mathrm{a}}$ & $51.18 \pm 0.24^{\mathrm{a}}$ & $32.48 \pm 0.17^{\mathrm{a}}$ & $63.46 \pm 0.28^{a}$ \\
\hline Significance level & $* *$ & $* *$ & $* *$ & $* *$ \\
\hline \multicolumn{4}{|c|}{ Interactions } & $60.82 \pm 0.78^{b}$ \\
\hline E1 X P2 & $65.73 \pm 0.69^{a}$ & $50.21 \pm 0.24^{\mathrm{b}}$ & $31.43 \pm 0.42^{\mathrm{b}}$ & $62.60 \pm 0.65^{a}$ \\
\hline E1 X P3 & $66.40 \pm 0.27^{\mathrm{a}}$ & $50.64 \pm 0.37^{b}$ & $31.02 \pm 0.16^{\mathrm{b}}$ & $63.24 \pm 0.26^{\mathrm{a}}$ \\
\hline E2 X P1 & $65.67 \pm 0.50^{\mathrm{a}}$ & $50.57 \pm 0.34^{\mathrm{b}}$ & $31.63 \pm 0.23^{\mathrm{b}}$ & $62.54 \pm 0.48^{a}$ \\
\hline E2 X P2 & $67.13 \pm 0.32^{\mathrm{a}}$ & $51.50 \pm 0.17^{\mathrm{a}}$ & $32.93 \pm 0.15^{\mathrm{a}}$ & $63.94 \pm 0.31^{\mathrm{a}}$ \\
\hline E2 X P3 & $66.78 \pm 0.53^{\mathrm{a}}$ & $51.71 \pm 0.22^{\mathrm{a}}$ & $32.93 \pm 0.25^{\mathrm{a}}$ & $63.68 \pm 0.51^{\mathrm{a}}$ \\
\hline Significance level & ** & $* *$ & $* *$ & $* *$ \\
\hline
\end{tabular}

higher egg weight and egg mass versus those received diets with 150 and $130 \mathrm{~g} \mathrm{CP} / \mathrm{kg}$. In addition, hen fed diets with $130 \mathrm{~g} \mathrm{CP} / \mathrm{kg}$ decreased feed intake and worsened feed conversion ratio per $\mathrm{kg}$ of eggs. Silva et al. (2010) reported that reducing dietary CP from 180 to $120 \mathrm{~g} / \mathrm{kg}$ diet resulted in linear decrease in egg weight and egg mass value even providing layer requirements for all essential amino acids. Rama Rao and Tirupathi Reddy (2016) found that egg production, egg mass and were increased in white leghorns as dietary energy and protein increased. On the other side Kumari et al. (2016) observed that EP, FI, EW were not influenced by different protein levels in WLH layers'diet from 25-44 weeks of age Similarly, Mousavi et al. (2013) observed that EP was not affected by the reduction in dietary protein level from (18.5-15.5\%), without any alteration in digestible total sulfur amino acids and threonine: lysine ratio.

The calculated analysis of the experimental diets showed that in order to reach a constant level of SAA, this requires an increase in the level of methionine in low-protein diets whose lysine level is low due to reduction in soybean meal amount which has caused a disturbance in the amino acid balance and hence the balance of essential amino acids, especially in terms of total sulfur amino acids and lysine which are two first limiting amino acids is highly important when low-protein diets are fed. On the other hand, this strain seems unable to compensate for low dietary ME and CP content by increasing its feed intake sufficiently to meet energy and protein /or other nutrient (amino acids) requirements to gave best performance.

\section{Egg quality and reproductive parameters:}

Results revealed that there no significant variations $(\mathrm{P} \leq 0.05)$ were observed in egg quality, fertility percentage and chick weight due to feeding on different energy and protein levels as shown in Tables (5 and 6). These results are agreement with Tenesa et al. (2016) who fed Hisex brown hens: 17.5\% CP (control); $17.5 \%, 17 \%$ and $16.5 \% \mathrm{CP}$ supplemented with amino acid and they found no significant differences $(\mathrm{P}>0.05)$ in Haugh units, yolk and albumen weight percentage, eggshell weight and thickness among the treatment groups. Similarly, Tesfaye et al. (2019) noticed that no significant differences in egg quality, fertility and hatchability when hens fed on diets different protein-energy levels (16-2750, 16.5-2800, 172900 and 16\% CP-2700 ME kcal/kg diet). In the same trend, Hussein et al. (2010) reported that there were not significant differences in reproductive traits and egg quality of Sinai laying hens due to the experimental CP and ME levels. Yakout (2010) observed no significant differences by inclusion protein levels 17, 17.5, 15 and $13 \% \mathrm{CP}$ supplemented with amino acid in laying diets on egg quality as well Ding et al. (2016) observed 
Table (5): Effect dietary energy and protein levels fortified with methionine and their interactions on fertility and hatchability of Montazah laying hens.

\begin{tabular}{|c|c|c|c|c|c|}
\hline \multirow{2}{*}{\multicolumn{2}{|c|}{ Treatment }} & $\begin{array}{c}\text { Fertility } \\
\%\end{array}$ & $\begin{array}{c}\text { Hatchability of fertile } \\
\text { egg \% }\end{array}$ & $\begin{array}{l}\text { Hatchability of total } \\
\text { egg \% }\end{array}$ & $\begin{array}{c}\text { Chick weight } \\
(\mathrm{g})\end{array}$ \\
\hline & & & Energy levels (E) & & \\
\hline \multirow{2}{*}{\multicolumn{2}{|c|}{$\begin{array}{l}\text { E } 12700 \mathrm{kcal} / \mathrm{kg} \\
\text { E } 22850 \mathrm{kcal} / \mathrm{kg}\end{array}$}} & $86.59 \pm 0.33$ & $88.84 \pm 0.56$ & $76.91 \pm 0.40$ & $33.30 \pm 0.37$ \\
\hline & & $87.70 \pm 0.50$ & $89.27 \pm 0.68$ & $78.28 \pm 0.54$ & $34.17 \pm 0.38$ \\
\hline \multirow{2}{*}{\multicolumn{2}{|c|}{ Significance level }} & NS & NS & NS & NS \\
\hline & & & Protein levels (P) & & \\
\hline & $14 \%$ & $86.86 \pm 0.67$ & $88.84 \pm 0.86$ & $77.14 \pm 0.49$ & $33.50 \pm 0.45$ \\
\hline & $16 \%$ & $86.98 \pm 0.61$ & $88.90 \pm 0.91$ & $77.31 \pm 0.73$ & $33.95 \pm 0.41$ \\
\hline P 3 & $18 \%$ & $87.60 \pm 0.40$ & $89.43 \pm 0.52$ & $78.34 \pm 0.64$ & $33.75 \pm 0.55$ \\
\hline \multicolumn{2}{|c|}{ Significance level } & NS & $\begin{array}{c}\mathrm{NS} \\
\text { Interactions }\end{array}$ & NS & NS \\
\hline \multicolumn{2}{|c|}{ E1 X P1 } & $86.31 \pm 0.76$ & $88.57 \pm 1.57$ & $76.43 \pm 0.42$ & $33.30 \pm 0.67$ \\
\hline \multicolumn{2}{|c|}{$\mathrm{E} 1 \mathrm{X} \mathrm{P} 2$} & $86.46 \pm 0.75$ & $88.66 \pm 0.35$ & $76.65 \pm 0.48$ & $33.50 \pm 0.60$ \\
\hline \multicolumn{2}{|c|}{ E1 X P3 } & $86.98 \pm 0.17$ & $89.29 \pm 1.03$ & $77.66 \pm 0.87$ & $33.10 \pm 0.72$ \\
\hline \multicolumn{2}{|c|}{ E2 X P1 } & $87.40 \pm 1.19$ & $89.10 \pm 1.10$ & $77.85 \pm 0.40$ & $33.70 \pm 0.63$ \\
\hline \multicolumn{2}{|c|}{ E2 X P2 } & $87.50 \pm 1.02$ & $89.14 \pm 1.99$ & $77.97 \pm 1.42$ & $34.40 \pm 0.54$ \\
\hline \multicolumn{2}{|c|}{ E2 X P3 } & $88.21 \pm 0.61$ & $89.57 \pm 0.53$ & $79.01 \pm 0.92$ & $34.40 \pm 0.82$ \\
\hline \multicolumn{2}{|c|}{ Significance level } & NS & NS & NS & NS \\
\hline
\end{tabular}

Table (6): Means of egg quality measurements as affected by dietary energy levels and protein levels fortified methionine and their interaction in Montazah laying hens.

\begin{tabular}{|c|c|c|c|c|c|c|c|c|c|c|}
\hline \multirow{2}{*}{\multicolumn{2}{|c|}{ Treatment }} & \multirow{2}{*}{$\begin{array}{c}\text { Egg } \\
\text { shape } \\
\text { Index \% }\end{array}$} & \multicolumn{3}{|c|}{ Egg component } & \multirow{2}{*}{$\begin{array}{c}\text { Shell } \\
\text { thickness } \\
(\mathrm{mm})\end{array}$} & \multirow{2}{*}{$\begin{array}{l}\text { Hough } \\
\text { Unit }\end{array}$} & \multirow{2}{*}{$\begin{array}{c}\text { Yolk } \\
\text { index } \\
\%\end{array}$} & \multirow[b]{2}{*}{$\begin{array}{l}\text { Specific } \\
\text { gravity }\end{array}$} & \multirow[b]{2}{*}{ ESA } \\
\hline & & & $\begin{array}{c}\text { Albumen } \\
\%\end{array}$ & Yolk \% & $\begin{array}{c}\text { Shell } \\
\%\end{array}$ & & & & & \\
\hline \multicolumn{11}{|c|}{ Energy levels (E) } \\
\hline E1 2 & & 75.92 & 54.68 & 30.91 & 14.50 & 34.33 & 81.41 & 46.61 & 1.111 & 64.17 \\
\hline kcal & & \pm 0.81 & \pm 0.72 & \pm 0.46 & \pm 0.77 & \pm 0.50 & \pm 1.22 & \pm 1.05 & \pm 0.00 & \pm 0.93 \\
\hline E2 2 & & 77.59 & 54.45 & 30.99 & 14.41 & 34.56 & 80.56 & 48.39 & 1.109 & 63.61 \\
\hline kcal & & \pm 1.21 & \pm 0.77 & \pm 0.63 & \pm 0.50 & \pm 0.34 & \pm 2.01 & \pm 0.46 & \pm 0.00 & \pm 1.02 \\
\hline Sign & evel & NS & NS & NS & NS & NS & NS & NS & NS & NS \\
\hline \multicolumn{11}{|c|}{ Protein levels $(\mathrm{P})$} \\
\hline \multirow{2}{*}{\multicolumn{2}{|c|}{ P $1 \quad 14 \%$}} & 77.90 & 54.23 & 30.57 & 15.19 & 34.67 & 81.41 & 49.07 & 1.110 & 64.74 \\
\hline & & \pm 1.84 & \pm 0.78 & \pm 1.95 & \pm 0.91 & \pm 0.67 & \pm 2.97 & \pm 0.62 & \pm 0.00 & \pm 0.59 \\
\hline \multirow{2}{*}{\multicolumn{2}{|c|}{ P 2}} & 75.87 & 54.97 & 30.89 & 14.14 & 34.00 & 81.53 & 47.07 & 1.109 & 65.12 \\
\hline & & \pm 0.58 & \pm 1.15 & \pm 0.97 & \pm 0.30 & \pm 0.37 & \pm 1.86 & \pm 0.35 & \pm 0.00 & \pm 1.27 \\
\hline \multirow{2}{*}{\multicolumn{2}{|c|}{ P $3 \quad 18 \%$}} & 76.51 & 54.49 & 31.39 & 14.03 & 34.67 & 80.00 & 46.35 & 1.110 & 61.82 \\
\hline & & \pm 1.60 & \pm 0.82 & \pm 0.66 & \pm 0.97 & \pm 0.49 & \pm 0.91 & \pm 1.53 & \pm 0.01 & \pm 1.16 \\
\hline \multicolumn{2}{|c|}{$\begin{array}{l}\text { Sign. level } \\
\text { Interactions }\end{array}$} & NS & NS & NS & NS & NS & NS & NS & NS & NS \\
\hline \multirow{2}{*}{\multicolumn{2}{|c|}{ E1 X P1 }} & 76.47 & 54.41 & 30.75 & 14.84 & 34.33 & 82.02 & 48.33 & 1.110 & 65.35 \\
\hline & & \pm 0.64 & \pm 1.53 & \pm 0.38 & \pm 1.79 & \pm 1.33 & \pm 1.41 & \pm 1.13 & \pm 0.01 & \pm 0.95 \\
\hline \multirow{2}{*}{\multicolumn{2}{|c|}{ E1 X P2 }} & 75.95 & 54.90 & 30.72 & 14.38 & 34.00 & 81.45 & 46.64 & 1.111 & 66.15 \\
\hline & & \pm 0.89 & \pm 1.16 & \pm 1.06 & \pm 0.31 & \pm 0.58 & \pm 3.47 & \pm 0.38 & \pm 0.01 & \pm 1.35 \\
\hline \multirow{2}{*}{\multicolumn{2}{|c|}{ E1 X P3 }} & 75.35 & 54.74 & 31.27 & 14.27 & 34.67 & 80.77 & 44.87 & 1.111 & 61.02 \\
\hline & & \pm 2.54 & \pm 1.58 & \pm 1.09 & \pm 1.94 & \pm 0.88 & \pm 1.84 & \pm 2.98 & \pm 0.01 & \pm 0.35 \\
\hline \multirow{2}{*}{\multicolumn{2}{|c|}{ E2 X P1 }} & 79.33 & 54.06 & 30.40 & 15.54 & 35.00 & 80.82 & 49.82 & 1.110 & 64.13 \\
\hline & & \pm 2.93 & \pm 0.83 & \pm 0.10 & \pm 0.87 & \pm 0.58 & \pm 6.46 & \pm 0.25 & \pm 0.00 & \pm 0.70 \\
\hline \multirow{2}{*}{\multicolumn{2}{|c|}{ E2 X P2 }} & 75.78 & 55.05 & 31.06 & 13.90 & 34.00 & 81.62 & 47.49 & 1.108 & 64.10 \\
\hline & & \pm 0.94 & \pm 2.30 & \pm 1.88 & \pm 0.54 & \pm 0.58 & \pm 2.29 & \pm 0.52 & \pm 0.00 & \pm 2.28 \\
\hline \multirow{2}{*}{\multicolumn{2}{|c|}{ E2 X P3 }} & 77.67 & 54.24 & 31.51 & 13.80 & 34.67 & 79.24 & 47.84 & 1.108 & 62.61 \\
\hline & & \pm 2.23 & \pm 0.89 & \pm 0.98 & \pm 0.96 & \pm 0.67 & \pm 0.40 & \pm 0.77 & \pm 0.01 & \pm 2.44 \\
\hline Sign & icance & NS & NS & NS & NS & NS & NS & NS & NS & NS \\
\hline
\end{tabular}

All means in the same column were not significantly. 
that there was no significant interaction between ME (2650 and $2750 \mathrm{kcal} / \mathrm{kg})$ and CP $(14.5,15$ and $15.5 \%$ ) on egg quality and discrepancy with Zeweil et al. (2011) who showed that increasing CP level significantly decreased hatched percentage of chicks of Baheij hens.

\section{Blood parameters:}

The effects of energy and dietary protein levels supplemented with methionine and their interactions on some blood parameters are summarized in Table (7). Results based on effects of energy levels showed that there were not significant differences in most blood parameters; total protein, albumin, globulin AST, ALT and glucose in response to feeding on low-energy diet than that high-energy diet but cholesterol level was significantly reduced $(\mathrm{P} \leq 0.01)$. Increasing protein level caused to significant differences $(\mathrm{P} \leq 0.01)$ in values of AST and ALT whereas hens received diet containing 18\% CP displayed significant increasing in ALT in blood plasma than that fed $14 \% \mathrm{CP}$, while other parameters were not affected.

Interactions between studied factors are presented in Table (7). Statistical analysis revealed significant differences in AST, ALT and cholesterol in blood plasma; however, there were not significant differences in

Table (7): Effect of dietary energy levels and protein fortified with methionine and their interactions on some blood parameters of Montazah laying hens.

\begin{tabular}{|c|c|c|c|c|c|c|c|}
\hline Treatment & $\begin{array}{l}\text { Total } \\
\text { protein } \\
\text { g/dl }\end{array}$ & $\begin{array}{l}\text { Albumin } \\
\mathrm{g} / \mathrm{dl}\end{array}$ & $\begin{array}{l}\text { Globulin } \\
\text { g/dl }\end{array}$ & $\begin{array}{l}\mathrm{AST} \\
\mathrm{U} / \mathrm{L})\end{array}$ & $\begin{array}{l}\text { ALT } \\
(\mathrm{U} / \mathrm{L})\end{array}$ & $\begin{array}{c}\text { Cholesterol } \\
\mathrm{mg} / \mathrm{dl}\end{array}$ & $\begin{array}{c}\text { Glucose } \\
\mathrm{mg} / \mathrm{dl}\end{array}$ \\
\hline \multicolumn{8}{|c|}{ Energy levels (E) } \\
\hline \multirow[t]{2}{*}{ E1 $2700 \mathrm{kcal} / \mathrm{kg}$} & 4.40 & 2.58 & 1.82 & 20.22 & 26.67 & 115.11 & 248.56 \\
\hline & \pm 0.05 & \pm 0.04 & \pm 0.05 & \pm 1.48 & \pm 0.88 & $\pm 0.53^{\mathrm{b}}$ & \pm 1.04 \\
\hline \multirow[t]{2}{*}{ E2 $2850 \mathrm{kcal} / \mathrm{kg}$} & 4.52 & 2.64 & 1.88 & 17.78 & 26.67 & 121.56 & 249.78 \\
\hline & \pm 0.06 & \pm 0.06 & \pm 0.07 & \pm 0.70 & \pm 0.65 & $\pm 1.45^{\mathrm{a}}$ & \pm 0.89 \\
\hline \multirow[t]{2}{*}{$\begin{array}{c}\text { Significance } \\
\text { level }\end{array}$} & NS & NS & NS & NS & NS & $* *$ & NS \\
\hline & \multicolumn{7}{|c|}{ Protein levels $(\mathrm{P})$} \\
\hline $14 \%$ & 4.43 & 2.63 & 1.80 & 15.67 & 25.50 & 116.67 & 248.00 \\
\hline & \pm 0.05 & \pm 0.04 & \pm 0.04 & $\pm 0.67^{\mathrm{b}}$ & $\pm 0.76^{\mathrm{b}}$ & \pm 1.33 & \pm 0.73 \\
\hline $16 \%$ & 4.47 & 2.68 & 1.78 & 22.00 & 25.33 & 117.67 & 248.83 \\
\hline & \pm 0.08 & \pm 0.05 & \pm 0.07 & $\pm 1.48^{\mathrm{a}}$ & $\pm 0.42^{\mathrm{b}}$ & \pm 1.20 & \pm 1.47 \\
\hline \multirow[t]{2}{*}{$18 \%$} & 4.48 & 2.52 & 1.97 & 19.33 & 29.17 & 120.50 & 250.67 \\
\hline & \pm 0.08 & \pm 0.07 & \pm 0.10 & $\pm 0.84^{\mathrm{a}}$ & $\pm 0.48^{\mathrm{a}}$ & \pm 2.72 & \pm 1.15 \\
\hline \multirow[t]{2}{*}{$\begin{array}{c}\text { Significance } \\
\text { level }\end{array}$} & NS & NS & NS & $* *$ & $* *$ & NS & NS \\
\hline & \multicolumn{7}{|c|}{ Interactions } \\
\hline \multirow[t]{2}{*}{ E1 X P1 } & 4.40 & 2.60 & 1.80 & 15.67 & 24.33 & 114.67 & 248.67 \\
\hline & \pm 0.06 & \pm 0.06 & \pm 0.12 & $\pm 1.20^{\mathrm{c}}$ & $\pm 0.88^{\mathrm{d}}$ & $\pm 1.20^{\mathrm{c}}$ & \pm 0.88 \\
\hline \multirow[t]{2}{*}{ E1 X P2 } & 4.43 & 2.67 & 1.76 & 24.67 & 26.00 & 115.33 & 246.67 \\
\hline & \pm 0.09 & \pm 0.09 & \pm 0.03 & $\pm 1.76^{\mathrm{a}}$ & $\pm 0.58^{\mathrm{cd}}$ & $\pm 0.67^{\mathrm{bc}}$ & \pm 2.19 \\
\hline \multirow[t]{2}{*}{ E1 X P3 } & 4.37 & 2.47 & 1.90 & 20.33 & 29.67 & 115.33 & 250.33 \\
\hline & \pm 0.12 & \pm 0.03 & \pm 0.10 & $\pm 1.33^{\mathrm{b}}$ & $\pm 0.88^{\mathrm{a}}$ & $\pm 0.88^{\mathrm{bc}}$ & \pm 2.03 \\
\hline \multirow[t]{2}{*}{ E2 X P1 } & 4.47 & 2.67 & 1.80 & 15.67 & 26.67 & 118.67 & 247.33 \\
\hline & \pm 0.09 & \pm 0.07 & \pm 0.06 & $\pm 0.88^{\mathrm{c}}$ & $\pm 0.88^{\mathrm{bc}}$ & $\pm 1.86^{\mathrm{bc}}$ & \pm 1.20 \\
\hline \multirow[t]{2}{*}{ E2 X P2 } & 4.50 & 2.70 & 1.80 & 19.33 & 24.67 & 120.00 & 251.00 \\
\hline & \pm 0.15 & \pm 0.06 & \pm 0.07 & $\pm 0.88^{\mathrm{bc}}$ & $\pm 0.33^{\mathrm{cd}}$ & $\pm 1.16^{\mathrm{b}}$ & \pm 1.16 \\
\hline \multirow[t]{2}{*}{ E2 X P3 } & 4.60 & 2.57 & 2.03 & 18.33 & 28.67 & 126.00 & 251.00 \\
\hline & \pm 0.06 & \pm 0.15 & \pm 0.03 & $\pm 0.88^{\mathrm{bc}}$ & $\pm 0.33^{\mathrm{ab}}$ & $\pm 2.31^{\mathrm{a}}$ & \pm 1.53 \\
\hline Significance & NS & NS & NS & $* *$ & $* *$ & $* *$ & NS \\
\hline
\end{tabular}


AST value among hens received diets different protein levels and high energy level but the lowest value of AST was recorded by hens fed low-protein diet with any energy levels compared with other treatment groups. In contrast the highest value of cholesterol was recorded by hens fed diet containing $18 \% \mathrm{CP}$ and $2850 \mathrm{kcal} / \mathrm{kg}$ diet. These results agreement with the findings of Nofal et al. (2018), who observed increasing cholesterol in blood plasma as a result of feeding hens on high-energy diet (2800 kcal/kg diet) compared with the low-energy diets (2600 kcal/kg diet) but plasma levels of albumin, glucose and activity of AST were not affected. Similarly Kout El-kloub et al. (2005) illustrated that blood parameters were not affected by different protein and energy levels in laying hens and disagreement with Zeweil et al. (2011) who reported that plasma total protein and globulin concentrations of laying hens fed diet containing $16 \% \mathrm{CP}$ more than those fed 12 or $14 \%$ CP-diet.

\section{Economic efficiency of feed (EEF):}

In Table (8) it can be postulated that feed intake is considered one of the important factors to calculate $\mathrm{EE}$, decreasing feed intake in response to fed different protein levels and high-energy diets resulted in decreased in feed cost (55.47 LE, 56.57 LE and 57.99 LE) than those the same level of protein and lowenergy diets (56.94 LE, 59.01LE and 58.46 LE) and with raising of Price of fertile eggs/hen and net return which reflected in higher in EEF. Although hens fed 16\% CP-diet achieved the highest of total price of egg fertile, total return, net return and EEF however, hens received 14\% CP and high-energy diets was similar in total price of egg fertile, total return, net return and EEF than that fed 16 and 18\% CP at the same energy level compared with other treatment groups.

Table (8): Effect of dietary energy levels and protein levels fortified with methionine and their interactions on economic efficiency of feed (EEF) of Silver Montazah laying hens.

\begin{tabular}{lccccccc}
\hline Treatment & $\begin{array}{c}\text { Total } \\
\text { feed } \\
\text { intake of } \\
\text { hen(kg) }\end{array}$ & $\begin{array}{c}\text { Price of } \\
\text { feed cost } \\
\text { /hen L. E }\end{array}$ & $\begin{array}{c}\text { Return BWG } \\
\text { L. E }\end{array}$ & $\begin{array}{c}\text { Total Price } \\
\text { of fertile } \\
\text { eggs/hen LE }\end{array}$ & $\begin{array}{c}\text { Total } \\
\text { return } \\
\text { L. E }\end{array}$ & $\begin{array}{c}\text { Net } \\
\text { return L. } \\
\text { E }\end{array}$ & $\begin{array}{c}\text { Relative } \\
\text { EE\% }\end{array}$ \\
\hline E1 X P1 & 12.33 & 56.94 & 2.78 & 152.55 & 155.33 & 98.39 & 172.86 \\
& \pm 0.06 & \pm 0.27 & \pm 0.16 & \pm 1.88 & \pm 1.86 & \pm 1.84 & \pm 3.33 \\
E1 X P2 & 12.43 & 59.01 & 3.89 & 156.30 & 160.19 & 101.17 & 171.51 \\
& \pm 0.06 & \pm 0.28 & \pm 0.07 & \pm 1.50 & \pm 1.54 & \pm 1.55 & \pm 2.86 \\
E1 X P3 & 11.75 & 58.46 & 4.14 & 158.85 & 162.99 & 104.53 & 179.10 \\
& \pm 0.09 & \pm 0.46 & \pm 0.18 & \pm 0.48 & \pm 0.53 & \pm 0.81 & \pm 2.66 \\
E2 X P1 & 11.60 & 55.74 & 4.44 & 157.50 & 161.94 & 106.20 & 190.90 \\
& \pm 0.10 & \pm 0.48 & \pm 0.15 & \pm 1.10 & \pm 1.10 & \pm 1.32 & \pm 3.66 \\
E2 X P2 & 11.30 & 56.57 & 4.69 & 160.95 & 165.64 & 109.07 & 192.98 \\
& \pm 0.07 & \pm 0.33 & \pm 0.19 & \pm 0.65 & \pm 0.73 & \pm 0.87 & \pm 2.37 \\
E3 X P3 & 11.13 & 57.99 & 5.12 & 160.20 & 165.32 & 107.33 & 185.29 \\
& \pm 0.06 & \pm 0.30 & \pm 0.14 & \pm 1.15 & \pm 1.15 & \pm 1.33 & \pm 3.00 \\
\hline
\end{tabular}

1-Total feed cost then L. E= Feed intake $x$ price of $\mathrm{kg}$ feed.

2- Return $B W G=B W G X$ price of $\mathrm{kg} B W$ at time of experiment $=35 \mathrm{~L} . E$.

3- Total price of fertile eggs then $L$. E = total No. of fertile egg then x price of fertile egg at time of experiment $=225 P t$.

4-Total return $=$ Total price of fertile eggs then L. E+ Return BWG.

5- Net return $=$ Total return - Price of feed cost.

6- Relative economic efficiency $=$ Net return $/$ Price of feed cost $* 100$. 


\section{REFERENCES}

Ahmad H. A.; M. M. Bryant; S. Kucuktas; D. A. Roland (1997). Econometric feeding and management for first cycle phase two Deklab Delta hens. Poultry Science; 76: 1256-1263.

Bryant, M.; Wu G., and D. A. Roland Sr. (2005). Optimizing dietary energy for profit and performance of two strains of White Leghorns. International Poult. Sci., Forum Abstracts, Atlanta. GA, USA. Page 23.

Carter, T. C. (1974). The hen's egg estimation of shell superficial area and egg volume from four shell measurements. Br. Poult. Sci., 15: (5) 507-511

Carter, T. C. (1975). The hen's egg: A rapid method for routine estimation of flock means shell thickness. Br. Poultry. Sci., 16 (2): 131-143.

Chaiyapoom B. and S. Taweesak (2005). Effects of adding metionine in low-protein diet on production performance, reproductive organs and chemical liver composition of laying hens under tropical conditions. Int. J. of Poult. Sci., 4 (5): 301-308.

Ding, Y.; X. Bu; N. Zhang; L. Li and X. Zou (2016). Effects of metabolizable energy and crude protein levels on laying performance, egg quality and serum biochemical indices of Fengda-1 layers. Animal Nutrition, 2: (2): 93-98.

Duncan, D. B. (1955). Multiple range and multiple F-tests. Biometrics. 11: 1-42

Gheisar, M. M., F. Foroudi and A. Ghazikhani (2011). Effect of using L-threonine and reducing dietary levels of crude protein on egg production in layers. Iran. J. Appl. Anim. Sci., 1: 65-68.

Grobas S., J. Mendez, C. De Blas, and G. G. Mantoes (1999). laying hen productivity as affected by energy, supplemental fat, and linoleic acid concentration of the diet. Poult. Sci., 78: 1542-1551.

Harms R. H.; A. F. Rossi; D. R. Sloan; R. D. Miles and R. B. Christmas (1990). A Method for estimating shell weight and correcting specific gravity for egg weight in eggshell quality studies. Poult. Sci., 69 (1): 48-52.

Harms, R. H.; G. B. Russel and D. R. Sloan (2000). Performance of four strains of commercial layers with major changes in dietary energy. Journal of Applied Poultry Research, 9: 535-541.

Hassan, G. M.; M. Farghaly; F. N. K. Soliman and H. A. Hussain (2000). The influence of strain and dietary protein level on egg production traits for different local chicken strains. Egypt. Poult. Sci., 20: 49-63.

Hussein, M. A. A.; Kout El-Kloub M. El. Mostafa; M. K. Gad El-Hak and A. M. Abbas (2010). Optimal metabolizable energy and crude protein levels for Sinai laying hens. Egypt. Poult. Sci., 30: IV, 1073:1095.

Keshavarz, K. (1995). Further investigations on the effect of dietary manipulations of nutrients on early egg weight. Poult. Sci. 74:62-74.

Keshavartz, K. and S. Nakajima (1995). The effect of dietary manipulations of energy, protein, and fat during the growing and laying periods on early egg weight and egg components. Poult. Sci., 74 (1): 5061 .

Keshavarz, K. and M. E. Jackson (1992). Performance of growing pullets and laying hens fed low-protein, amino acid-supplemented diets. Poult. Sci., 71: 905-918.

Kout EL-Kloub, M.El. Moustafa; M. A. A. Hussein and M. K. Gad El-hak (2005). A study on the energy and protein requirements of Mamourah local strain chickens during laying hens. Egypt Poult. Sci., Vol (25) (III): (637-651).

Kumari, K. N. R.; K. R. Chandra and D. S. Kumar (2016). Effect of protein levels in diet on production and emissions in WHL layer. Adv. Anim. and Vet. sci., Vol. 4 (7): 357-362.

Larbier, M. and B. Leclercq (1994). Nutrition and Feeding of Poultry," Nottingham University Press, Loughborough, p. 305.

Latshaw, J. D. and L. Zhao (2011). Dietary protein effects on hen performance and nitrogen excretion. Poult. Sci., 90: 99-106. 


\section{Alderey}

Leeson, S. (1989). Energy intake and layer performance. Pages 72-79 in Proc. Calif. Nutr. Conf. Grain Feed Assoc. Fresno.

Mareiy Y. A.; M. A. Ibrahim; R. M. Mahmoud and H. A. Abo Khashaba (2009). Influence of nutrient density on productive and reproductive performance of four local laying hen strains. Egypt. Poult. Sci., 29: 527:564.

Meluzzi, A.; F. Sirri; N. Tallarico and A. Franchini (2001). Nitrogen retention and performance of brown laying hens on diets with different protein content and constant concentration of amino acids and energy. Br. Poult. Sci., 42:213-217.

Mousavi, S. N.; S. Khalaji; A. Ghasemi-Jirdehi and F. Foroudi (2013). Investigation on the effects of dietary protein reduction with constant ratio of digestible sulfur amino acids and threonine to lysine on performance, egg quality and protein retention in two strains of laying hens. Ital. J. Anim. Sci., 12: 9-12.

Nahashon, S. N.; S. E. Aggrey; N. A. Adefope; A. Amenyenu and D. Wright (2010). Gompertz-Laird model prediction of optimum utilization of crude protein and metabolizable energy by French guinea fowl broilers. Poult Sci. 89:52-57.

Nofal M. E.; H. R. Samak; A. A. Alderey and A. M. E. Nasr (2018). Effect of dietary folic acid supplementation to diets of low levels of energy and methionine of developed laying hens in summer season on performance, physiological status and immune response. J. Animal and Poultry Prod., Mansoura Univ., Vol.9 (12): 471 - 480.

NRC (1994). Nutrient Requirements of Poultry. 9th rev. ed. Nat. acad. Press. Washington, DC

Omara, Islam I.; M. and Ramy M. Romeilah (2009). Energy and methionine utilization in laying hen diets supplementation with folic acid. Research Journal of Agriculture and Biological Sciences, 5 (4): 428 444.

Rama Rao, S. V. and E. Tirupathi Reddy (2016). Effect of different levels of dietary crude protein, lysine and methionine on performance of White Leghorn laying hens. Asian Journal of Poult. Sci., Vol. 10 (3): $147-152$.

Saki A. A.; R. Naseri Harsini; M. M. Tabatabaei; P. Zamani and M. Haghight (2012). Estimates of Methionine and Sulfur Amino Acid Requirements for Laying Hens using Different Models. Brazilian J. of Poult. Sci., Vol. 14 (NO. 3) 159-232

Salah Uddin M.; A. M. M. Tareque; M. A. R. Howlider; M. Jasimuddin Khan and S. Ahmed (1992). Effect of dietary protein and energy levels on the performance of Starcross layers. AJAS 1992 Vol. 5 (No. 4) 723-731.

Silva, M. F. R.; D. E. Faria,; P. W. Rizzoli; A. L. Santos; M. I. Sakamoto and H. R. B. Souza (2010). Performance, egg quality and nitrogen balance of commercial laying hens fed diets with different levels of crude protein and lysine. R. Bras. Zootec. 39, 1280-1285.

Silva Viana (2017) Responses to reduction on dietary crude protein and supplementation of non-essential nitrogen; dietary essential to non-essential nitrogen optimum ratio for white commercial layers. Postgraduate bachelor's in animal science, for obtaining the title of Doctor Scientiae. Viçosa Minas Gerais - BRASIL.

SPSS (2011). Statistical Package for Social Sciences Version 20.0. IBM SPSS Inc., NY, USA.

Tenesa, M.; T. C. Loh; H. L. Foo; A. A. Samsudin; R. Mohamad and A. R. Raha (2016). Effects of feeding different levels of low crude protein diets with different levels of amino acids supplementation on layer hen performance. Pertanika J. Trop. Agric. Sci. 39 (4): 543 - 555.

Tesfaye, E.; W. Esatu; K. Melese and T. Habte (2019). Effect of energy-protein optimization on the growth and production performance of local chickens. Acta Scientific Nutritional Health 3:(2): 04-12.

Van Emous, R. A.; R. P. Kwakkel; M. M. van Krimpen; H. van den Brand and W. H. Hendriks (2015). Effects of growth patterns and dietary protein levels during rearing of broiler breeders on fertility, hatchability, embryonic mortality and offspring performance. Poult. Sci., 94: 681-691.

Wu, G.; Bryant M. M.; R. A. Voitle; D. A. Sr Roland (2005). Effect of dietary energy on performance and egg composition of Bovans white and Dekalb white hens during phase 1. Poult. Sci., 84(10):1610-5. 
Wu, G.; M. M. Bryant, P. Gunawardana and D. A. Roland Sr. (2007). Effect of nutrient density on performance, egg components, egg solids, egg quality and profits in eight commercial Leghorn strains during phase one. Poult. Sci., 86: 691-697.

Yakout, H. M. (2010). Effects of reducing dietary crude protein with amino acids supplementation on performance of commercial white leghorn layers during the second production period. Egypt. Poult. Sci., 30: 961-974.

Yakout, H. M. (2000). Response of laying hens to practical and low protein diets with ideal TSAA: Lysine ratios: Effects on egg production component, nitrogen and nitrogen excretion. Ph.D. Thesis, Alexandria University, Alexandria, Egypt.

Yakout, H. M.; M. E. Omara; Y. Marie and R. A. Hassan (2004). Effect of incorporating growth promoters and different dietary protein level into Mandarah hens layers diets. Egypt. Poult. Sci., 24: 977-994.

Zimmerman, R. A. (1997). Management of egg size through precise nutrient delivery. J. Applied Poult. Res., 6: $478-482$.

Zeweil, H. S.; A. A. Abdalla; M. H. Ahmed and Marwa R. S. Ahmed (2011). Effect of different levels of protein and methionine on performance of Baheij laying hens and environmental pollution. Egypt. Poult. Sci., 31: (2): 621-639.

\title{
تأثير مستويات البروتين المنخفضة المدعمة بالمثيونين مع الطاقةتلى الاداء الاتتاجى والتناسلى لاجاج المنتزة الفضى البياض
}

\author{
عبد الفتاح عبد الحميد الارعى \\ معطج بحوث الإنتاج الحيوانى - مركز البحوث الزراعية - الاقى - جيزة- مصر.
}

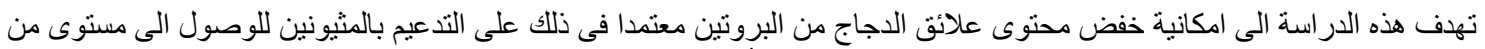

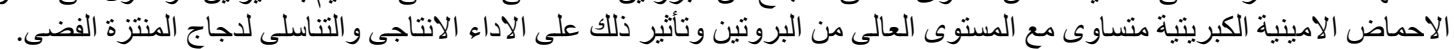

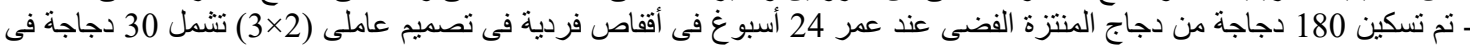

كل معاملة.

ـ ـ تم تكوين العلائق التجريبية بمستويين من الطاقة (مستوى الطاقة المنخفض 2700 ومستوى الطاقة العالى 2850 وكن كيلو كالورى طاقة

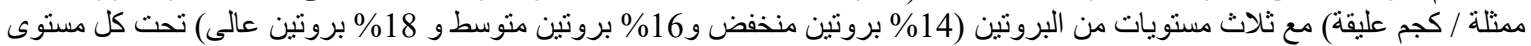

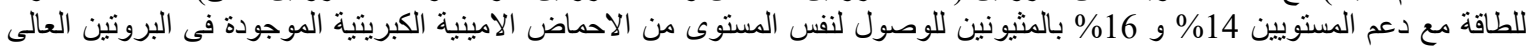

ـ ـ تم تقديم العليقة والماء بصورة حرة. تم تقدير نسب الخصوبة و الفقس عند 37, 38, 39 أسبوع من العمر حيث أن دجاجات كل معاملة

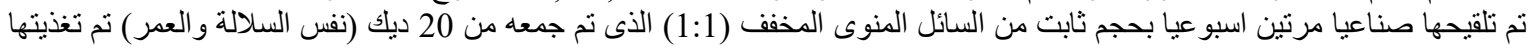

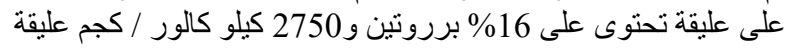

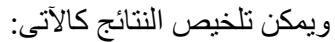

1- لوحظ زيادة معنوية فى وزن الجسم النهائى والتغير فى وزن الجسم ونسبة كفاءة الطاقة الممثلة ونسبة التحوبل الغذائى وقياسات انتاج

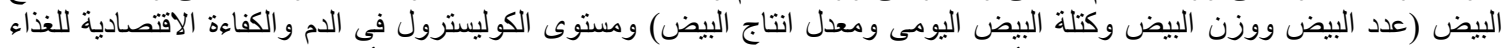

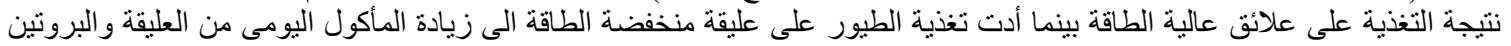
و الطاقة والمثيونين مقارنة بنلك النى تغذت على على علائق عالية الطاقة.

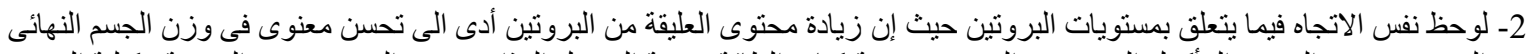

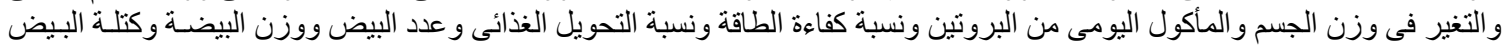

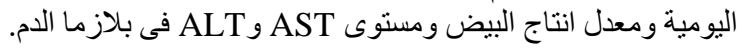

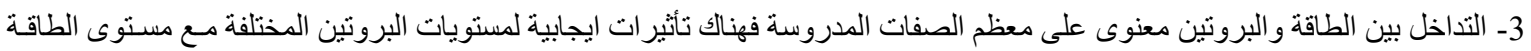

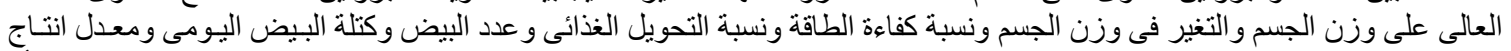

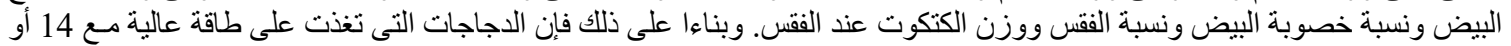

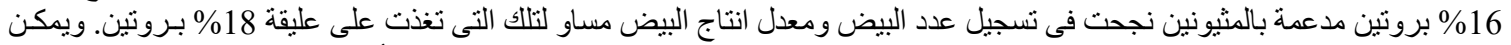

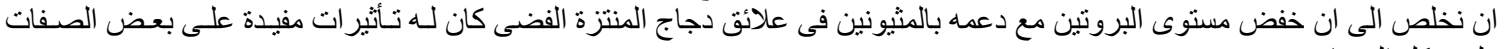

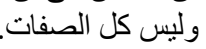

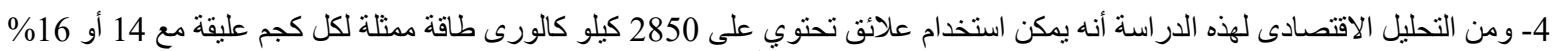
بروتين مدعمة بالمثيونين فى تغذية دجاج المنتزة الفضى خلال 24-40 أسبوع دون الاضرى بلان بالربحية. 